\title{
Boron Deficiency in Trifoliate Orange Induces Changes in Pectin Composition and Architecture of Components in Root Cell Walls
}

\author{
Xiuwen Wu, Muhammad Riaz, Lei Yan, Chenqing Du, Yalin Liu and Cuncang Jiang* \\ College of Resources and Environment, Huazhong Agricultural University, Wuhan, China
}

\section{OPEN ACCESS}

Edited by: Giampiero Cai,

University of Siena, Italy

Reviewed by:

Sergio Esposito,

University of Naples Federico II, Italy

Frantisek Baluska

University of Bonn, Germany

${ }^{*}$ Correspondence:

Cuncang Jiang

jcc2000@mail.hzau.edu.cn

Specialty section:

This article was submitted to

Plant Nutrition,

a section of the journal

Frontiers in Plant Science

Received: 29 July 2017

Accepted: 17 October 2017

Published: 08 November 2017

Citation:

Wu X, Riaz M, Yan L, Du C, Liu Y and Jiang $C$ (2017) Boron Deficiency in Trifoliate Orange Induces Changes in Pectin Composition and Architecture of Components in Root Cell Walls.

Front. Plant Sci. 8:1882. doi: $10.3389 /$ fpls.2017.01882
Boron (B) is a micronutrient indispensable for citrus and B deficiency causes a considerable loss of productivity and quality in China. However, studies on pectin composition and architecture of cell wall components in trifoliate orange roots under B deficiency condition are not sufficient. In this study, we investigated the alteration in pectin characteristics and the architecture of cell wall components in trifoliate orange [Poncirus trifoliata (L.) Raf.] roots under B starvation. The results showed that B-deficient roots resulted in a significant enlargement of root tips and an obvious decrease in cell wall $\mathrm{B}$ and uronic acid content in $\mathrm{Na}_{2} \mathrm{CO}_{3}$-soluble pectin compared with B-adequate roots. Meanwhile, they showed a decrease of 2-keto-3-deoxyoctanoic acid in CDTA-soluble and $\mathrm{Na}_{2} \mathrm{CO}_{3}$-soluble pectin in cell walls, while the degree of methylation (DM) of CDTA-soluble pectin was significantly increased under B deficiency. Transmission electron microscope (TEM) micrographs of B deficient plants showed a distinct thickening of the cell walls, with the thickness 1.82 times greater than that of control plant roots. The results from Fourier-transform infrared spectroscopy (FTIR) showed that B deficiency changed the mode of hydrogen bonding between protein and carbohydrates (cellulose and hemicellulose). The FTIR spectra exhibited a destroyed protein structure and accumulation of wax and cellulose in the cell walls under $\mathrm{B}$ starvation. The ${ }^{13} \mathrm{C}$ nuclear magnetic resonance $\left({ }^{13} \mathrm{C}-\mathrm{NMR}\right)$ spectra showed that B starvation changed the organic carbon structure of cell walls, and enhanced the contents of amino acid, cellulose, phenols, and lignin in the cell wall. The results reveal that the swelling and weakened structural integrity of cell walls, which induced by alteration on the network of pectin and cell wall components and structure in B-deficient roots, could be a major cause of occurrence of the rapid interruption of growth and significantly enlarged root tips in trifoliate orange roots under B-insufficient condition.

Keywords: boron, cell wall, pectin, ultrastructure, component

\section{INTRODUCTION}

Boron (B) is an essential micronutrient for higher plants. The deficiency of boron causes various growth defects mainly in the young and growing parts of plants (Loomis and Durst, 1992). Conclusive evidence shows that $\mathrm{B}$ deficiency is a widespread problem than any other micronutrient (Shorrocks, 1997). Boron deprivation causes a wide range of physiological and biochemical changes 
in allocation of B in cell walls, pectin composition, cell wall components and structure (Hu and Brown, 1994; Pan et al., 2012; Liu et al., 2013, 2014).

Several studies have demonstrated that B deficiency results in the swelling of the cell wall and changes in the cell wall polysaccharides, and B deficiency induces increase of cell wall porosity (Fleischer et al., 1999; Ishii et al., 2001; Kaku et al., 2002). The primary function of B is involved in the formation of cell walls through diester bridges between two rhamnogalacturonan II (RG-II) molecules to cross-link cell wall pectin (Ishii and Matsunaga, 1996; Kobayashi et al., 1996; O’Neill et al., 2001). Pectic polysaccharides are known to contribute to the mechanical strength and physical properties of primary walls by binding to B (Ridley et al., 2001). Matoh et al. (1996) provided evidence that RG-II is the unique binding site of B in most plants, and $\mathrm{B}$ concentration in cell walls was positively correlated to the characteristic sugar residue [2-keto-3-deoxyoctanoic acid (KDO)] of RG-II. It is widely accepted that pectin is synthesized in the Golgi and then secreted into the walls as highly methylesterified forms. The variation in the degree of methylation (DM) of pectin after releasing carboxyl groups leads to an alteration in the binding capacity of $\mathrm{B}(\mathrm{OH})$ in the synthesis of the cell wall structure (Kobayashi et al., 1996; O'Neill et al., 1996). Thus, DM of pectin determines the integrity of cell walls.

Citrus is one of the most important economic crops in China, and $\mathrm{B}$ deficiency is frequently observed in citrus orchards, causing loss of productivity and quality (Han et al., 2008; Jiang et al., 2009). Recent studies showed that B deficiency resulted in the alteration of citrus root morphology, physiological characteristics and apical subcellular structure (Lu et al., 2014; Zhou et al., 2014; Liu L.C. et al., 2015). Various studies have been carried out on the changes induced by B deficiency in the cellular structures of root tips and leaves in citrange (Liu L.C. et al., 2015), the structure and ultrastructure of roots and leaves in citrus (Mesquita et al., 2016), cellular B allocation and pectin composition in leaves of two citrus rootstocks and the architecture of cell wall components in navel orange leaves (Liu et al., 2013, 2014). Furthermore, the growth characteristics generally vary greatly between roots and leaves as well as rootstocks and grafted seedlings. Trifoliate orange [Poncirus trifoliata (L.) Raf.] is considered the most important rootstock of citrus, and is very sensitive to B deficiency. Root morphology and growth status have an important influence on the absorption of water and nutrients, which restrict the productivity and quality of citrus. Roots are the most sensitive organ to $B$ deficiency that results in the rapid inhibition of growth with a significantly enlarged root tip (Bohnsack and Albert, 1977). Recently, several have studied the root morphology, root vessel anatomy, metabolite profile and metabolic pathway under B deficiency condition (Wang R.D. et al., 2013; Liu G.D. et al., 2015; Dong et al., 2016).

Fourier-transform infrared spectroscopy (FTIR) and nuclear magnetic resonance (NMR) are important and appropriate techniques for analysis of the chemical composition of biological macromolecules and for identifying the structure of organic compounds dynamics (Griffiths and Haseth, 2007; Li et al., 2009; Wang Q.J. et al., 2013).
Although B deprivation has been frequently reported to induce obvious changes in the cell wall pectin composition and the architecture of cell wall components in the leaves of trifoliate orange rootstock seedlings with inadequate B. However, studies on the roots of trifoliate orange are not enough, especially in pectin composition of cell walls.

The aim of this study was to investigate (1) the changes in the pectin characteristics, exactly variations on KDO and DM in the B-deficient roots (2) the variations in the structure of organic compounds and components of root cell walls by the technique of trifoliate orange by method of transmission electron microscope (TEM), FTIR, and ${ }^{13} \mathrm{C}-\mathrm{NMR}$, and to gain a new insight into the mechanism of $B$ in the root cell walls of trifoliate orange.

\section{MATERIALS AND METHODS}

\section{Plant Material and Treatments}

The experiment was carried out in a greenhouse under natural sunlight conditions at Huazhong Agricultural University, Wuhan, China. Young plants of trifoliate orange [Poncirus trifoliate (L.) Raf.] rootstock with uniform root length $(5-6 \mathrm{~cm})$ and stem height $(6-7 \mathrm{~cm})$ were collected and grown in the hydroponics for 9 weeks. The modified Hoagland and Arnon (1950) solution was used as a nutrient culture solution containing the following macronutrients:

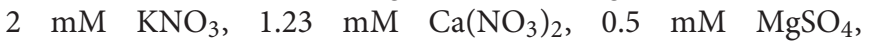
$0.14 \mathrm{mM} \mathrm{Na} \mathrm{HPO}_{4}, 0.32 \mathrm{mM} \mathrm{NaH} \mathrm{PO}_{4}, 9.15 \mu \mathrm{M} \mathrm{MnCl}$, $1.6 \mu \mathrm{M} \mathrm{ZnSO}{ }_{4}, 0.32 \mu \mathrm{M} \mathrm{CuSO}, 0.36 \mu \mathrm{M} \mathrm{Na}_{2} \mathrm{MoO}_{4}$, and $37.4 \mu \mathrm{M}$ Fe-EDTA. After being soaked in tap water for 2 days, plants were transplanted to 4-liter black plastic barrels with a nutrient solution with varying concentrations of $\mathrm{B}: 10 \mu \mathrm{M}$ $\mathrm{H}_{3} \mathrm{BO}_{3}$ (control treatment) and $0 \mu \mathrm{M} \mathrm{H}_{3} \mathrm{BO}_{3}$ (B deficiency treatment). The experiment was designed in a completely randomized with two treatments, and each treatment was replicated six times with one replication contained one seedling.

The culture solution was aerated for $20 \mathrm{~min}$ at a 4-h interval and renewed once a week. Analytical-grade reagents were used to prepare nutrient solutions. The $\mathrm{pH}$ was maintained between 5.8 and 6.2 every day using $0.5 \mathrm{M} \mathrm{H}_{2} \mathrm{SO}_{4}$ or $1 \mathrm{M} \mathrm{NaOH}$.

\section{Plant Sampling and Boron Analysis}

At the end of the experiment, all plants were harvested and rinsed in deionized water, then were divided into separate parts (roots, stems, and leaves). All the roots of each seedling were further separated into two portions, with one portion used for B analysis, and the other portion used for subcellular structure observation and extraction of cell walls.

For analysis of B contents, the root samples were dried in an oven at $75^{\circ} \mathrm{C}$ until a constant weight. The samples were ground to a fine powder after measuring the dry weight, and washed at $500^{\circ} \mathrm{C}$ for $5 \mathrm{~h}$, followed by dissolving the ashes in $10 \mathrm{~mL} 0.1 \mathrm{M}$ $\mathrm{HCl}$. The B concentration was measured spectrophotometrically at $540 \mathrm{~nm}$ (Hitachi UV-3100 UV/VIS; TECHCOMP, Shanghai, China) by the curcumin colorimetric method. 


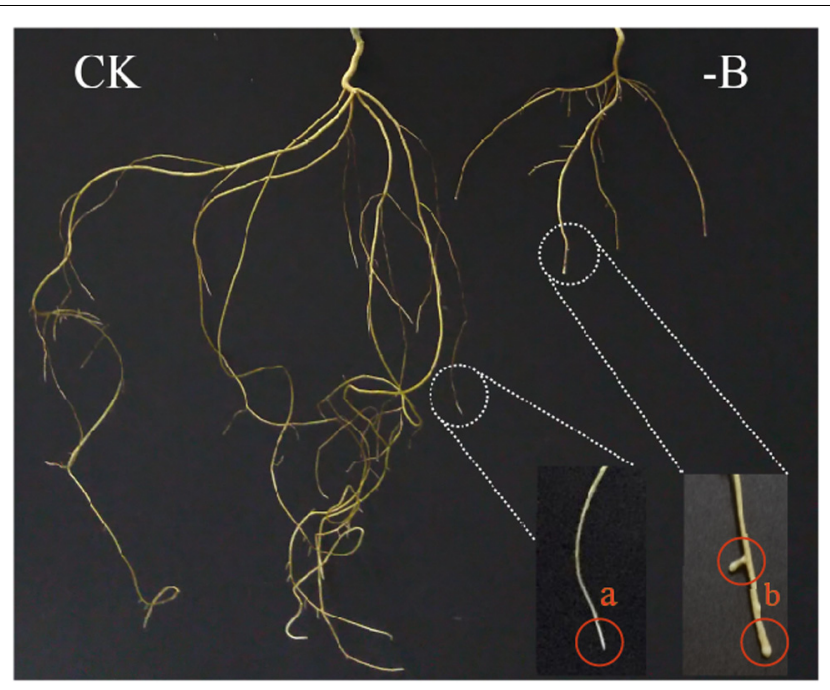

FIGURE 1 | Growth of trifoliate orange roots under different boron treatments (CK: $10 \mu \mathrm{M}$ B; -B: $0 \mu \mathrm{M}$ B). (a) Control plant: normal healthy root growth with longer main and lateral roots; (b) boron-deficient roots: stunted root growth with thickened root tips and fewer lateral roots.

\section{Preparation of Cell Wall Materials (CWM)}

The cell walls were extracted from the fresh roots of trifoliate orange by using the method described by $\mathrm{Hu}$ and Brown (1994). Briefly, fresh root samples were homogenized in liquid nitrogen with a mortar. After homogenization with $30 \mathrm{~mL}$ ice-cold ultrapure water and centrifugation at $5,000 \times g$ for $10 \mathrm{~min}$, the precipitate was washed with $30 \mathrm{~mL}$ ice-cold ultrapure water and re-centrifuged. Then the residue was washed three times with $30 \mathrm{~mL} 80 \%$ ethanol and once with $30 \mathrm{~mL}$ mixture of methanol/chloroform $(1 / 1, \mathrm{v} / \mathrm{v})$. Finally, the precipitate was washed with $30 \mathrm{~mL}$ acetone. The final insoluble pellet was defined as CWM. The CWM samples were dried in a freeze drier (SIMfreeze-drierFD5-3, Beckman) and weighed. The obtained CWM was divided into three portions: one portion was dried to ashes at $500^{\circ} \mathrm{C}$ for $\mathrm{B}$ determination following the procedure above, another portion was used for fractionation and determination of cell wall pectin, and the third portion was used for FTIR and ${ }^{13} \mathrm{C}$-NMR analysis.

\section{Preparation of Pectin}

Pectin was extracted as described by Redgwell and Selvendran (1986) with slight modifications. Briefly, the crude cell wall powder was suspended in $0.05 \mathrm{M}$ sodium acetate buffer $(\mathrm{pH}$ 6.5) containing $0.05 \mathrm{M}$ CDTA. After being stirred for $12 \mathrm{~h}$ at $24^{\circ} \mathrm{C}$ in a horizontal shaker, the supernatant was defined as CDTA-soluble pectin fraction. The CDTA-insoluble pellet was then re-suspended in $0.05 \mathrm{M} \mathrm{Na}_{2} \mathrm{CO}_{3}$ and incubated for $12 \mathrm{~h}$ at $24^{\circ} \mathrm{C}$. After centrifugation at $5,000 \times g$ for $20 \mathrm{~min}$ at $4^{\circ} \mathrm{C}$, the supernatant was designated as $\mathrm{Na}_{2} \mathrm{CO}_{3}$-soluble pectin fraction.

\section{Determination of Uronic Acid, 3-Deoxy-d-manno-2-octulosonic Acid (KDO), and the Degree of Methylation (DM) of Pectin}

The contents of uronic acid (UA) in CDTA-soluble and $\mathrm{Na}_{2} \mathrm{CO}_{3}$ soluble pectin fractions were determined by the method of Blumenkrantz and Asboe-Hansen (1973). A standard curve was constructed with galacturonic acid and measurements were done in quadruplicate.

The level of KDO was measured by the thiobarbituric acid method (York et al., 1985) with KDO as the standard.

The DM of the two different pectin fractions was determined following the method of Anthon and Barrett (2004) with minor modifications. Briefly, the mixture of $100 \mu \mathrm{L}$ of pectin extract and $50 \mu \mathrm{L}$ of $1.5 \mathrm{M} \mathrm{NaOH}$ was treated for $30 \mathrm{~min}$ at $25^{\circ} \mathrm{C}$, followed by the addition of $55 \mu \mathrm{L}(0.75 \mathrm{M}) \mathrm{H}_{2} \mathrm{SO}_{4}, 200 \mu \mathrm{L}$ of $0.2 \mathrm{M}$ Tris- $\mathrm{HCl}(\mathrm{pH} 7.5), 80 \mu \mathrm{L}$ of $3 \mathrm{mg} \mathrm{mL}^{-1} \mathrm{MBTH}$ and $20 \mu \mathrm{L}$ of alcohol oxidase (AO, 0.01 units $\mu \mathrm{L}^{-1}$ ) and then incubation for $20 \mathrm{~min}$ at $30^{\circ} \mathrm{C}$. The reaction was terminated by the addition of $400 \mu \mathrm{L}$ of solution containing $5 \mathrm{mg} \mathrm{mL}^{-1}$ of ammonium ferric sulfate and sulfaminic acid. Finally, after standing for $20 \mathrm{~min}$ at

TABLE 1 | Effect of boron deficiency on plant growth and dry weight of trifoliate orange seedlings.

\begin{tabular}{|c|c|c|c|c|c|}
\hline \multirow[t]{2}{*}{ Treatment } & \multirow[t]{2}{*}{ Root length (cm/plant) } & \multirow[t]{2}{*}{ Shoot length (cm/plant) } & \multicolumn{3}{|c|}{ Dry weight (g/plant) } \\
\hline & & & Root & Stem & Leaf \\
\hline $\mathrm{CK}$ & $40.70^{a *} \pm 3.20$ & $20.80^{a} \pm 0.90$ & $0.34^{a} \pm 0.01$ & $0.25^{\mathrm{a}} \pm 0.02$ & $0.26^{a} \pm 0.02$ \\
\hline$-B$ & $14.30^{\mathrm{b}} \pm 1.27$ & $11.16^{b} \pm 0.64$ & $0.16^{b} \pm 0.01$ & $0.17^{b} \pm 0.01$ & $0.10^{b} \pm 0.01$ \\
\hline
\end{tabular}

*Values are means of four replicates $\pm S D$. Columns with different letters $(a, b)$ are significantly different using the $T$-test $(n=6, P<0.05)$.

TABLE 2 | The assignment of boron in roots and cell walls of trifoliate orange roots.

\begin{tabular}{|c|c|c|c|c|}
\hline \multirow[t]{2}{*}{ Treatment } & \multirow{2}{*}{$\begin{array}{c}\text { Root B content } \\
\text { mg/kg dry weight }\end{array}$} & \multirow{2}{*}{$\begin{array}{l}\text { Cell wall B content } \\
\text { mg/kg dry weight }\end{array}$} & \multicolumn{2}{|c|}{ Cell wall B/Root B } \\
\hline & & & $\%$ & Increase (\%) \\
\hline CK & $14.29^{\mathrm{a} *} \pm 1.12$ & $20.29^{a} \pm 0.72$ & $27.45^{\mathrm{b}} \pm 3.26$ & - \\
\hline$-B$ & $8.05^{b} \pm 0.06$ & $18.68^{\mathrm{b}} \pm 0.48$ & $61.47^{\mathrm{a}} \pm 7.58$ & 123.93 \\
\hline
\end{tabular}

*Values are means of four replicates $\pm S D$. Columns with different letters $(a, b)$ are significantly different using the $T$-test $(n=6, P<0.05)$. 
TABLE 3 | Effect of boron deprivation on uronic acid, KDO, and DM of CDTA-soluble pectin and $\mathrm{Na}_{2} \mathrm{CO}_{3}$-soluble pectin in cell wall.

\begin{tabular}{|c|c|c|c|c|}
\hline & \multicolumn{2}{|c|}{ CDTA-soluble pectin } & \multicolumn{2}{|c|}{$\mathrm{Na}_{2} \mathrm{CO}_{3}$-soluble pectin } \\
\hline & CK & $-B$ & CK & $-B$ \\
\hline Uronic acid \% & $6.42^{a *} \pm 0.25$ & $5.22^{\mathrm{a}} \pm 0.15$ & $22.06^{a} \pm 0.59$ & $14.84^{\mathrm{b}} \pm 1.67$ \\
\hline $\mathrm{KDO} \%$ & $8.79^{a} \pm 0.79$ & $6.92^{b} \pm 0.54$ & $13.66^{\mathrm{a}} \pm 1.60$ & $9.30^{b} \pm 0.25$ \\
\hline DM\% & $17.30^{\mathrm{b}} \pm 1.18$ & $31.88^{a} \pm 2.18$ & $15.40^{\mathrm{a}} \pm 0.50$ & $16.35^{\mathrm{a}} \pm 1.34$ \\
\hline
\end{tabular}

*Values are means of four replicates $\pm S D$. Rows with different letters $(a, b)$ are significantly different using the T-test $(n=6, P<0.05)$.

room temperature, the reaction mixture was supplemented with $1,095 \mu \mathrm{L}$ of water and the absorbance was measured at $620 \mathrm{~nm}$ by a spectrophotometer.

\section{Preparation of Transmission Electron Microscope (TEM) Slices}

The preparation TEM slices were carried out by the method of Kong et al. (2013) with slight modification. Briefly, the root tips were embedded in paraffin and cut into small pieces. The samples were fixed in $2.5 \%$ glutaraldehyde in phosphate buffer solution (PBS) for $12 \mathrm{~h}$ at $4^{\circ} \mathrm{C}$. The samples were post-fixed in $1 \%$ buffered osmium tetroxide for $2-3 \mathrm{~h}$ and dehydrated using a mixture of $90 \%$ ethanol and $90 \%$ acetone for $15 \mathrm{~min}$. Ultrathin sections were stained with $2 \%$ uranyl acetate and lead citrate, and were examined with a TEM (Hitachi 500 electron microscope) at an acceleration voltage of $60 \mathrm{kV}$. For each treatment, at least four plants were analyzed and representative plant images were chosen for each B treatment. The cell wall thickness was measured with the "Ruler" tool in Adobe Photoshop CS6 by comparing with the scale in TEM images.

\section{Analysis of Composition and Structure of Cell Walls by Fourier-Transform Infrared Spectroscopy (FTIR)}

A small amount of cell wall powder was mixed uniformly with $\mathrm{KBr}(1 / 100, \mathrm{~m} / \mathrm{m})$ and pressed into tablets. IR spectra $(4,000-$ $400 \mathrm{~cm}^{-1}$ ) were recorded using a VERTEX 70 spectrometer with a resolution of $4 \mathrm{~cm}^{-1}$ and 32 scans per sample. The six copies of the spectra of cell walls with different B treatments were normalized and baseline-corrected with OMNIC 32 software, and graphical data were processed with Origin 8.6 software.

\section{Solid-State Nuclear Magnetic Resonance $\left({ }^{13} \mathrm{C}-\mathrm{NMR}\right)$ Spectroscopy Analysis}

The cell walls were ground to fine powder and passed through a $0.2 \mathrm{~mm}$ sieve. The ${ }^{13} \mathrm{C}-\mathrm{NMR}$ spectra were obtained on a fully automatic nuclear magnetic resonance spectrometer (Bruker Avance III 400) using a $4 \mathrm{~mm}$ magic angle probe at $100.63 \mathrm{MHz}$. The cross-polarization/total suppression of sidebands (CP/TOSS) NMR spectrum was recorded with a $1 \mathrm{~s}$ recycle delay and 4,096 scans.

\section{Statistical Analysis}

Graphs were prepared by Microsoft Excel 2010 and Origin 8.6 software. FTIR spectra were normalized and baseline-corrected
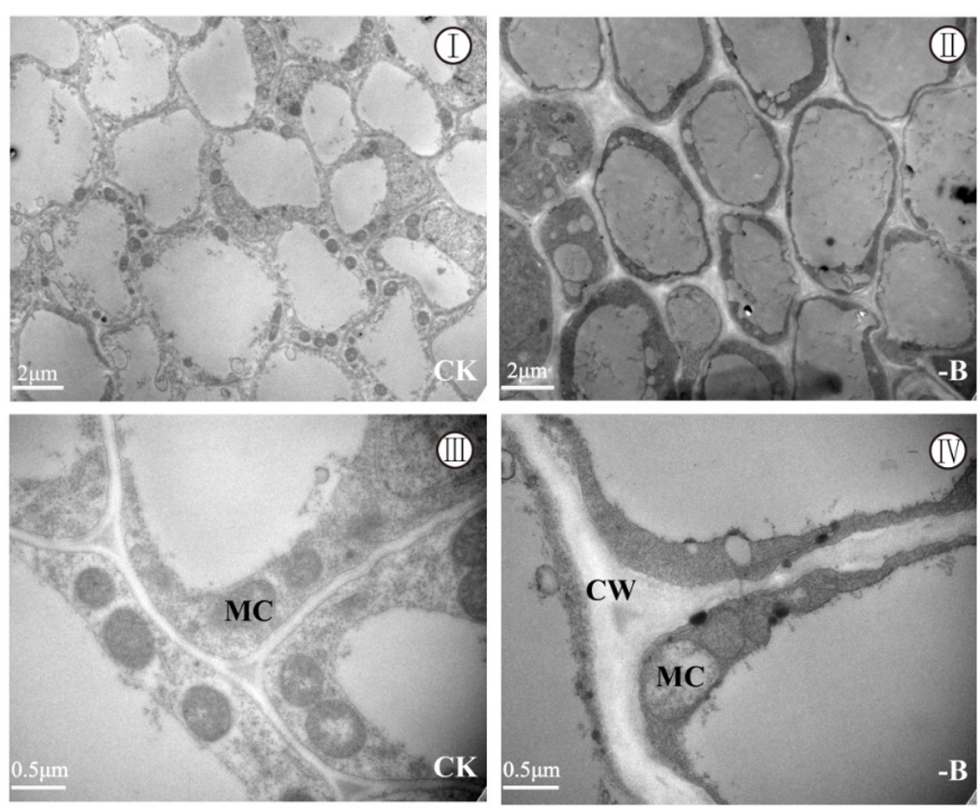
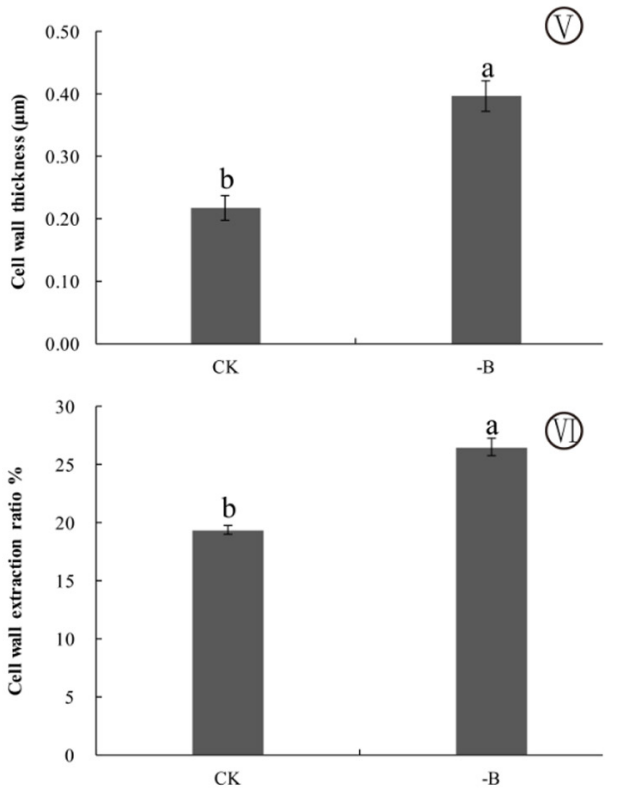

FIGURE 2 | Changes in subcellular structure and cell wall under two different boron treatments (CK: $10 \mu \mathrm{M} \mathrm{B;} \mathrm{-B:} 0 \mu \mathrm{M}$ B). Explanation of plate (I, II, III, IV: TEM micrographs of root cell; $\mathbf{V}$ : cell wall thickness; VI: cell wall extraction ratio; CW, cell wall; $\mathrm{MC}$, mitochondrion). Bars represent means of four replicates $\pm \mathrm{SD}$. Different letters in each group indicate significant differences at the $5 \%$ probability level. Cell wall extraction ratio \% = Dry weight of cell wall materials (g)/Dry weight of roots used for cell wall extraction $(\mathrm{g}) \times 100 \%$. Different letters $(\mathrm{a}, \mathrm{b})$ indicate the significant difference using the $T$-test $(n=6, P<0.05)$ between the two different boron treatments. 


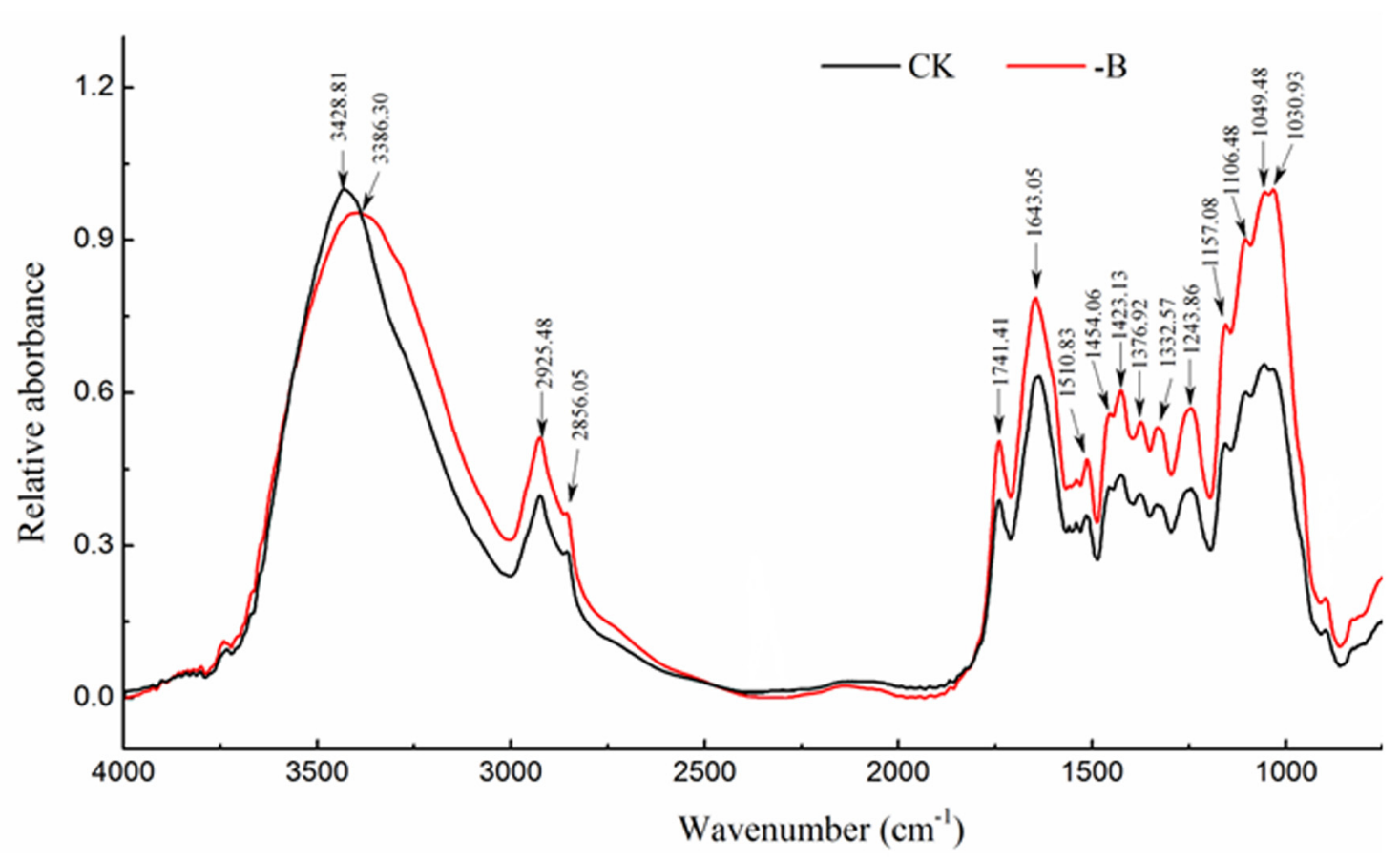

FIGURE 3 | FTIR spectral analysis of changes in the composition and structure of cell walls with different boron treatments (CK: $10 \mu \mathrm{M}$ B; -B: $0 \mu \mathrm{M}$ B).

with OMNIC 32 software, and then patterns were exported using Origin 8.6. The ${ }^{13} \mathrm{C}-\mathrm{NMR}$ data were analyzed with Topspin 3.2 and then plotted with Adobe Illustrator CS5. The data were statistically analyzed by SAS 9.1.3 software. Unless otherwise noted, results were presented as mean \pm SD of six replicates. Significant differences $(P<0.05)$ among treatments were determined by Tukey test and significant differences $(P<0.05)$ within each group were indicated by different lower case letters $(\mathrm{a}, \mathrm{b})$.

\section{RESULTS}

\section{Plant Growth and Dry Mass Accumulation}

The treatment of 9 weeks without B supply showed significant inhibition on the growth of trifoliate orange roots and swollen root tips. The plants exposed to B deprivation stress exhibited shorter root length and fewer lateral roots as compared with the control treatment (adequate $\mathrm{B}, 10 \mu \mathrm{M}$ ) (Figure 1). The length of B-starved root and shoot decreased $64.86 \%$ and $46.35 \%$, respectively (Table 1). Additionally, B deficiency remarkably reduced the dry mass accumulation of roots, stems, and leaves compared with the control treatment.

\section{Distribution of Boron in Roots and Cell Walls}

The results presented in Table 2 showed that B concentration in roots and cell walls were significantly decreased under B deprivation compared with the control. In B-deficient trifoliate orange seedlings, the proportion of cell wall B in root B was much greater than that of the control. These results suggested that B in roots was assigned preferentially to cell walls under B starvation.

\section{Changes in Uronic Acid, KDO, and DM of Two Different Pectins}

The UA and KDO content of CDTA-soluble pectin and $\mathrm{Na}_{2} \mathrm{CO}_{3}$ soluble pectin in the cell wall of roots were both decreased under B deprivation treatment compared with control treatment (Table 3), suggesting the inhibition of the synthesis of the two different kinds of pectin and the decrease of the binding sites of $\mathrm{B}$ in cell walls under $\mathrm{B}$ deficiency. It should be noted that $\mathrm{B}$ deprivation had a remarkable effect on $\mathrm{Na}_{2} \mathrm{CO}_{3}$-soluble pectin than CDTA-soluble pectin. Additionally, B deficiency increased the DM of CDTA-soluble pectin in roots (Table 3 ). The results suggested that the reduction of pectin and B binding sites induced by $B$ deficiency hindered the binding of B to cell wall, and the toughness of cell wall was destroyed because of the increase of DM of CDTA-soluble pectin.

\section{Analysis of Subcellular Structure, Thickness, and Extraction Ratio of Cell Wall of Roots}

Transmission electron microscope micrographs of the root tips showed a thickened cell wall in cells under B-deficient treatment (Figures 2II,IV) while the cell wall of root tips under normal condition was regular (Figures 2I,III). And B deficiency significantly resulted in the increase of cell wall extraction ratio 


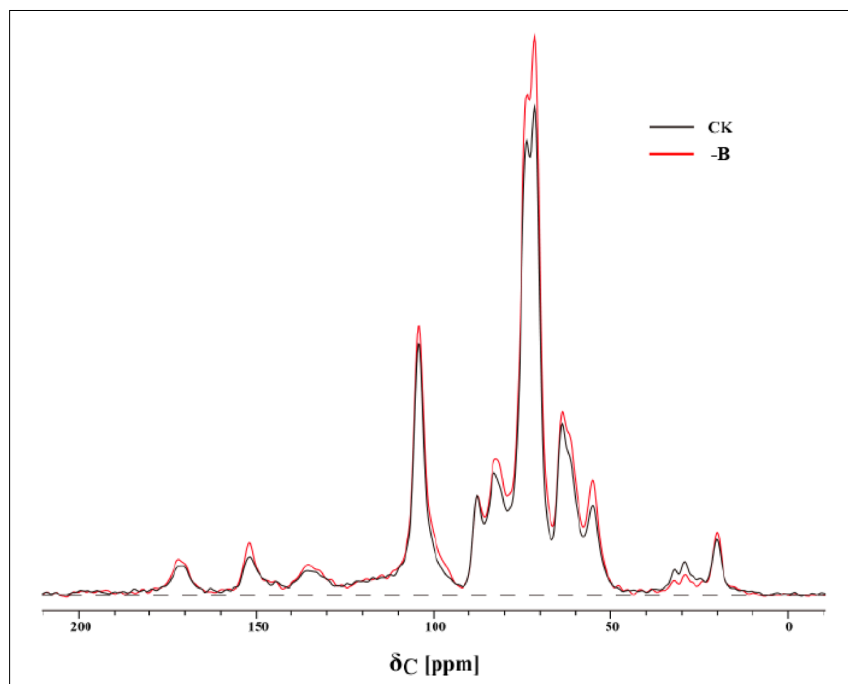

FIGURE $4 \mid{ }^{13} \mathrm{C}-\mathrm{NMR}$ spectra in cell walls of roots under normal boron supply (CK: $10 \mu \mathrm{M}$ B) and boron deficiency (-B: $0 \mu \mathrm{M}$ B).

(Figure 2VI). Additionally, there were fewer mitochondria in cells of B-starved roots. The cell wall thickness measured by Photoshop CS6 of B-deprived root tips was remarkably greater than that of the control (Figure 2V).

\section{Changes in Composition and Structure of Cell Wall of Roots}

In the present study, the differences of characteristic peaks between $\mathrm{CK}$ and $-\mathrm{B}$ were mainly observed in the region of $4,000-800 \mathrm{~cm}^{-1}$. The result showed that the relative absorbance corresponding to characteristic peaks of cell wall in B-deficient roots was higher than that in control roots (Figure 3).

As shown in Supplementary Table 1, the peak located around $3,430 \mathrm{~cm}^{-1}$ corresponded to $\mathrm{O}-\mathrm{H}$ and $\mathrm{N}-\mathrm{H}$ stretching vibrations and mainly related to protein and carbohydrates (Yang and Yen, 2002). B starvation resulted in the obvious shift from $3,428.81$ to $3,386.30 \mathrm{~cm}^{-1}$ was observed in cell walls, suggesting that B deficiency weakened the hydrogen bond between protein and carbohydrates (cellulose, hemicellulose). The higher intensity of 2,925 and $2,856 \mathrm{~cm}^{-1}$ in B-deficient spectra suggested the accumulation of wax and cellulose in cell walls. Moreover, spectra of cell walls from B-deficient roots had greater relative absorbance at $\sim 1,740 \mathrm{~cm}^{-1}$, which is characteristic of the $\mathrm{C}=\mathrm{O}$ stretching vibration of alkyl-esters in pectin. The peak at 1,643 and $1,510 \mathrm{~cm}^{-1}$ corresponded to amide I and amide II, respectively, while 1,330 and $1,245 \mathrm{~cm}^{-1}$ were attributed to $\mathrm{C}-\mathrm{N}$ stretching and $\mathrm{N}-\mathrm{H}$ deformation from amide III, respectively. Changes in those related peaks indicated that B starvation destroyed the protein structure of root cell walls. The enhanced intensity of $1,420 \mathrm{~cm}^{-1}$ was attributed to $-\mathrm{COO}^{-}$stretching in B-deficient cell walls, implying the increase of some amino acids. In addition, B deficiency significantly increased the relative concentration of cellulose as indicated by the enhanced characteristic peaks of cellulose $(1,454,1,376,1,050$, and 1,030 $\mathrm{cm}^{-1}$ ) (Figure 3). 


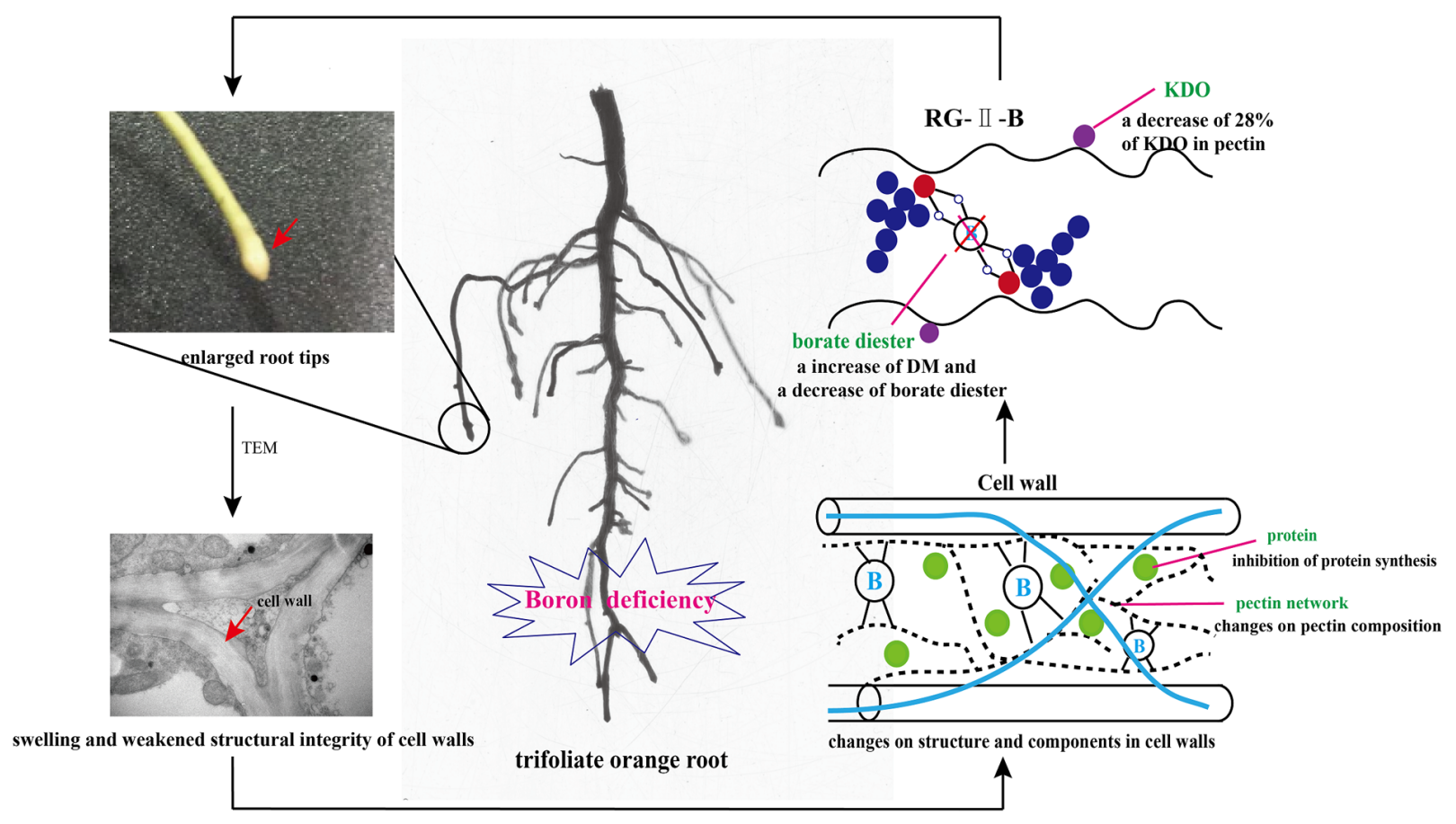

FIGURE 5 | Schematic diagram in the changes of cell walls in trifoliate orange roots due to boron (B) deficiency stress. Explanation of plate (KDO, 2-keto-3-deoxyoctanoic acid; DM, the degree of methylation of pectin).

\section{Changes in Organic Carbon of Cell Walls of Roots}

The ${ }^{13} \mathrm{C}$-NMR CP/TOSS spectra of cell walls could be divided into 8 resonance regions as shown in Supplementary Table 2 and Figure 4. The aliphatics (0-112 ppm) consisted of the alkyls C, the methoxyl $\mathrm{C}$, the carbohydrates $\mathrm{C}$ and the di-o-alkyl $\mathrm{C}$, while the aromatics (112-160 ppm) was associated with the aryl $\mathrm{C}$ and the phenolic C.

The variations in the organic carbon of cell walls under B-deficient and B-adequate conditions were observed (Table 4). Specifically, the organic carbon of cell walls of roots was dominated by aliphatics in the two groups. B deprivation increased the signals of $\mathrm{OCH}_{3}$ groups and OCHO groups, but decreased the signals of $\mathrm{C}_{\alpha \alpha}$-OR groups. Additionally, $\mathrm{B}$ deficiency induced obvious changes in aromatics $\mathrm{C}$, which was mainly reflected in $\mathrm{C}-\mathrm{O}$. The variation in those integrations suggested that $\mathrm{B}$ starvation changed the organic carbon structure of cell walls of roots, increased the contents of amino acids, cellulose, phenols and lignin in cell walls, and reduced the content of carbohydrate, mainly the soluble sugar.

\section{DISCUSSION}

It has been reported that $\mathrm{B}$ is required for the structural integrity of cell walls (O'Neill et al., 2001). The present study on trifoliate showed that B-deficient plants resulted in significant inhibition of root elongation and thickness root tips. Moreover, B-starved roots exhibited remarkably fewer mitochondria in the cells and dramatically increased of cell wall thickness and cell wall materials. Boron may affect the extensibility of cell walls not only via cross-linking of B-RG-II (O'Neill et al., 2001) but also by affecting the distribution of pectins cross-linked with calcium (Ca) (Matoh and Kobayashi, 1998). Previous study have indicated that B and Ca cross-linked pectins can be internalized via endocytosis in root apex cells, and their internalization might prove to be of critical importance for growth, polarity, and morphogenesis of roots (Baluska et al., 2002, 2005; Dhonukshe et al., 2006). Under B deprivation, abundance of pectins rapidly increased in cell walls of maize and wheat (insensitive to $B$ deficiency) root apices because of the inhibition on their internalization, whereas root cell walls of species sensitive to B deprivation, like zucchini and alfalfa, did not show accumulation of pectins and internalization of cell wall pectins under $B$ deficiency (Yu et al., 2002). Besides, aluminum (Al) toxicity in several aspects also thickened cell walls and inhibited endocytosis of cell wall pectins (Shen et al., 2008; Wu et al., 2015), and supply of $\mathrm{B}$ has been proved to alleviate $\mathrm{Al}$ toxicity in higher plants, possibly via cell wall pectins (Stass et al., 2007; Zhou et al., 2015). In the present study, B deficiency decreased the UA contents and $\mathrm{KDO}$ (the characteristic sugar residue of RG-II) of CDTA-soluble pectin and $\mathrm{Na}_{2} \mathrm{CO}_{3}$-soluble pectin of trifoliate orange roots, suggesting that $\mathrm{B}$ binding sites in cell walls were reduced and the network of pectin was modified by B starvation. Additionally, B deprivation significantly increased the DM of CDTA-soluble pectin, which may weaken the structure of cell walls in trifoliate orange roots. Consistent with this, the intensity of absorbance at $1,736 \mathrm{~cm}^{-1}$ was higher in B-deficient root cell wall, indicating 
the strengthening of the $\mathrm{C}=\mathrm{O}$ stretching vibration of alkyl-esters in pectin. It is worth mentioning that pectic polysaccharides influence the expansion, thickness and porosity of the cell walls and B-RG-II compounds in cell walls provide mechanical strength to the cell wall and structure (O'Neill et al., 2001). Therefore, alteration on distribution patterns and properties of pectin in cell walls may destroy the integrity of cell walls in trifoliate orange roots.

Hydrogen bonding is the most prevalent bonding type between the macromolecules in the cell walls. A large number of hydrogen bonds contribute to establishing a tight but flexible connection between macromolecules as the bonds can be easily opened and reformed due to their low bonding strength (Burgert and Dunlop, 2011). FTIR spectra from cell walls of B-starved roots exhibited a remarkable shift to the lower frequency corresponded to $\mathrm{O}-\mathrm{H}$ and $\mathrm{N}-\mathrm{H}$ stretching vibrations and are associated with mainly protein and carbohydrates, indicating that $\mathrm{B}$ deficiency destroyed the linkage pattern between protein and carbohydrates. In addition, the decrease of some corresponding peaks in cell walls indicates the inhibition of the protein synthesis and showed destroyed cell walls structure due to $\mathrm{B}$ starvation. The ${ }^{13} \mathrm{C}$-NMR spectra further revealed the increased relative content of methoxyl $\mathrm{C}$ associated with amino acids. The cell walls contained a variety of wall-associated proteins, and the structural proteins supports in the mechanical strength of the wall and facilitate the proper assembly of other wall components (Jamet et al., 2006).

Boron deficiency not only increased the amount of cellulose but also changed its architecture in cell walls. Similar results were also obtained in leaf cell walls of a navel orange (Liu et al., 2014) and roots of rape (Yang and Yen, 2002). It has been reported that the myo-inositol oxidation pathway plays a very important role in cell wall polysaccharide (cellulose) biosynthesis (Loewus and Murthy, 2010), and a significant decrease was observed in the myo-inositol concentration of B-starved leaves of navel orange (Liu G.D. et al., 2015; Dong et al., 2016). Thus the increase of cellulose may be related to changes induced by $\mathrm{B}$ deprivation in the myo-inositol oxidation pathway. As a complex macromolecule covalently, lignin plays an essential role in linking polysaccharides in plant cell walls and performing important biological functions (Tzin and Galili, 2010). It has been suggested that B could participate in lignin metabolism (Bellaloui, 2012) and lignin biosynthesis was obviously increased in trifoliate orange roots under B-deprived conditions (Dong et al., 2016). Our ${ }^{13} \mathrm{C}-\mathrm{NMR}$ spectral results showed higher relative contents of aryl $\mathrm{C}$ and phenolic $\mathrm{C}$ from lignin under $\mathrm{B}$ deprivation, suggesting a prominent promoting effect of B deficiency on lignin biosynthesis in cell walls of roots.

Phenolic compounds, generated from pentose phosphate pathway (PPP), are important secondary metabolites in plants. B starvation obviously promoted accumulation of phenols in cell walls of roots due to the entry of substantial amounts of respiratory substrates into PPP. Furthermore, accumulation of phenols caused a rapid rise of polyphenol oxidase activity, thereby resulting in the production of a large amount of active quinone and oxyradical (Shkol'Nik et al., 1981). Dordas and Brown (2005) suggested that the increase of phenols due to B deficiency be a secondary effect on the death of cells.

Changes in the structure of cell walls were correlated with the destruction of hydrogen bonding between carbohydrates/protein and network structure of pectin, and higher lignin in cell walls aggravated suberification in roots without adequate $B$. These results suggest that the changes induced by $\mathrm{B}$ starvation in the composition and structure of cell walls determine, to some extent, B deficiency symptoms of roots. A schematic summary, describing the key responses on pectin characters, cell wall structure and components in B-deficient trifoliate orange roots, and their relationships between the occurrence of B starvation symptoms of roots and changes on cell walls, is proposed in Figure 5.

\section{CONCLUSION}

$B$ deficiency induced a decrease in the $\mathrm{Na}_{2} \mathrm{CO}_{3}$-soluble pectin content in root cell walls and inhibited the synthesis or secretion of RG-II in pectin. Meanwhile, the DM of CDTA-soluble pectin was increased in the cell walls of B-deprived roots, and weakened the cell wall structural integrity. Additionally, B deficiency influenced the hydrogen bond between protein and carbohydrates (cellulose, hemicellulose) and promoted the accumulation of cellulose and phenolic compounds in cell walls. Therefore, the alteration in the architecture of cell wall components such as pectin, protein and cellulose, as well as the linkage pattern among them is closely related to the reduced capabilities of $\mathrm{B}$ binding. The results contribute to a better understanding of the mechanism of $\mathrm{B}$ in root cell walls and the root B deprivation symptoms, especially in the fields of rootstocks.

\section{AUTHOR CONTRIBUTIONS}

XW and CJ designed and supervised this study; XW conducted the experiments, performed data interpretation, and drafted the manuscript; LY and CD helped replace nutrition solution in the experiment and determine $\mathrm{B}$ concentration; YL helped revise the manuscript in grammar. All authors read and approved the final manuscript.

\section{FUNDING}

This work was supported by the National Natural Science Foundation of China (41271320) and the Fundamental Research Funds for the Central Universities (2017PY055).

\section{SUPPLEMENTARY MATERIAL}

The Supplementary Material for this article can be found online at: https://www.frontiersin.org/articles/10.3389/fpls.2017.01882/ full\#supplementary-material 


\section{REFERENCES}

Anthon, G. E., and Barrett, D. M. (2004). Comparison of three colorimetric reagents in the determination of methanol with alcohol oxidase. Application to the assay of pectin methylesterase. J. Agric. Food Chem. 52, 3749-3753. doi: $10.1021 /$ jf035284w

Baluska, F., Hlavacka, A., Samaj, J., Palme, K., Robinson, D. G., Matoh, T., et al. (2002). F-actin-dependent endocytosis of cell wall pectins in meristematic root cells. Insights from brefeldin A-induced compartments. Plant Physiol. 130, 422-431. doi: 10.1104/pp.007526

Baluska, F., Liners, F., Hlavacka, A., Schlicht, M., Van, C. P., McCurdy, D. W., et al. (2005). Cell wall pectins and xyloglucans are internalized into dividing root cells and accumulate within cell plates during cytokinesis. Protoplasma 225, 141-145. doi: 10.1007/s00709-005-0095-5

Bellaloui, N. (2012). Phomopsis seed infection effects on soybean seed phenol, lignin, and isoflavones in maturity group $\mathrm{V}$ genotypes differing in phomopsis resistance. J. Crop Improv. 26, 693-710. doi: 10.1080/15427528.2012.671236

Blumenkrantz, N., and Asboe-Hansen, G. (1973). New method for quantitative determination of uronic acids. Anal. Biochem. 54, 484-489. doi: 10.1016/00032697(73)90377-1

Bohnsack, C. W., and Albert, L. S. (1977). Early effects of boron deficiency on indoleacetic acid oxidase levels of squash root tips. Plant Physiol. 59, 1047. doi: 10.1104/pp.59.6.1047

Burgert, I., and Dunlop, J. W. C. (2011). Micromechanics of Cell Walls, Mechanical Integration of Plant Cells and Plants. Berlin: Springer, 27-52. doi: 10.1007/9783-642-19091-9_2

Dhonukshe, P., Baluška, F., Schlicht, M., Hlavacka, A., Samaj, J., Friml, J., et al. (2006). Endocytosis of cell surface material mediates cell plate formation during plant cytokinesis. Dev. Cell 10, 137-150. doi: 10.1016/j.devcel.2005.11.015

Dong, X. C., Liu, G. D., Wu, X. W., Lu, X. P., Muhammad, R., Yan, L., et al. (2016). Different metabolite profile and metabolic pathway with leaves and roots in response to boron deficiency at the initial stage of citrus rootstock growth. Plant Physiol. Biochem. 108, 121-131. doi: 10.1016/j.plaphy.2016.07.007

Dordas, C., and Brown, P. H. (2005). Boron deficiency affects cell viability, phenolic leakage and oxidative burst in rose cell cultures. Plant Soil 268, 293-301. doi: 10.1007/s11104-004-0309-1

Fleischer, A., O'Neill, M. A., and Ehwald, R. (1999). The pore size of non-graminaceous plant cell walls is rapidly decreased by borate ester crosslinking of the pectic polysaccharide rhamnogalacturonan II. Plant Physiol. 121, 829-838. doi: 10.1104/pp.121.3.829

Griffiths, P. R., and Haseth, J. A. D. (2007). Fourier Transform Infrared Spectrometry, 2nd Edn. Hoboken, NJ: John Wiley \& Sons.

Han, S., Chen, L. S., Jiang, H. X., Smith, B. R., Yang, L. T., and Xie, C. Y. (2008). Boron deficiency decreases growth and photosynthesis, and increases starch and hexoses in leaves of citrus seedlings. J. Plant Physiol. 165, 1331-1341. doi: 10.1016/j.jplph.2007.11.002

Hoagland, D. R., and Arnon, D. I. (1950). The Water-Culture Method for Growing Plants without Soil. Berkeley, CA: University of California, 1-32.

$\mathrm{Hu}, \mathrm{H}$., and Brown, P. H. (1994). Localization of boron in cell walls of squash and tobacco and its association with pectin (Evidence for a structural role of boron in the cell wall). Plant Physiol. 105, 681-689. doi: 10.1104/pp.105. 2.681

Ishii, T., and Matsunaga, T. (1996). Isolation and characterization of a boronrhamnogalacturonan -II complex from cell walls of sugar beet pulp. Carbohydr. Res. 284, 1-9. doi: 10.1016/0008-6215(96)00010-9

Ishii, T., Matsunaga, T., and Hayashi, N. (2001). Formation of rhamnogalacturonan II-borate dimer in pectin determines cell wall thickness of pumpkin tissue. Plant Physiol. 126, 1698-1705. doi: 10.1104/pp.126.4.1698

Jamet, E., Canut, H., Boudart, G., and Pont-Lezica, R. F. (2006). Cell wall proteins: a new insight through proteomics. Trends Plant Sci. 11, 33-39. doi: 10.1016/j. tplants.2005.11.006

Jiang, C. C., Wang, Y. H., Liu, G. D., Xia, Y., Peng, S. A., and Zhong, B. L. (2009). Effect of boron on the leaves etiolation and fruit fallen of newhall navel orange. Plant Nutr. Fertil. Sci. 15, 656-661.

Kaku, T., Tabuchi, A., Wakabayashi, K., Kamisaka, S., and Hoson, T. (2002). Action of xyloglucan hydrolase within the native cell wall architecture and its effect on cell wall extensibility in azuki bean epicotyls. Plant Cell Physiol. 43, 21-26. doi: $10.1093 / \mathrm{pcp} / \mathrm{pcf004}$
Kobayashi, M., Matoh, T., and Azuma, J. (1996). Two chains of rhamnogalacturonan II are cross-linked by borate-diol ester bonds in higher plant cell walls. Plant Physiol. 110, 1017-1020. doi: 10.1104/pp.110.3.1017

Kong, Y., Xu, X. Y., and Zhu, L. (2013). Cyanobactericidal effect of Streptomyces sp. HJC-D1 on Microcystis auruginosa. PLOS ONE 8:e57654. doi: 10.1371/journal. pone.0057654

Li, X., Liu, P., and Zhang, Z. X. (2009). Comparative research on wastewater treatment with two hydrophytes by FTIR. Spectrosc. Spectral Anal. 29, 945-949.

Liu, G. D., Dong, X. C., Liu, L. C., Wu, L. S., Peng, S. A., Wang, Y. H., et al. (2014). Boron deficiency is correlated with changes in cell wall structure that lead to growth defects in the leaves of navel orange plants. Sci. Hortic. 17, 654-662. doi: 10.1016/j.scienta.2014.06.036

Liu, G. D., Wang, R. D., Liu, L. C., Wu, L. S., Peng, S. A., Wang, Y. H., et al. (2013). Cellular boron allocation and pectin composition in two citrus rootstock seedlings differing in boron-deficiency response. Plant Soil 370, 555-565. doi: 10.1007/s11104-013-1659-3

Liu, G. D., Wang, R. D., Wu, L. S., Peng, S. A., Wang, Y. H., and Jiang, C. C. (2015). Differential changes in cell wall content and boron and calcium concentration in 'Newhall' navel orange grafted on two rootstocks differing in boron-deficiency responses. Commun. Soil Sci. Plant Anal. 46, 439-453. doi: 10.1080/00103624.2014.997384

Liu, L. C., Jiang, C. C., Dong, X. C., Wu, X. W., Liu, G. D., and Lu, X. P. (2015). Effects of boron deficiency on cellular structures of maturation zone from root tips and functional leaves from middle and upper plant in trifoliate orange rootstock. Sci. Agric. Sin. 48, 4957-4964.

Loewus, F. A., and Murthy, P. P. N. (2010). myo-Inositol metabolism in plants. Plant Sci. 150, 1-19. doi: 10.1016/S0168-9452(99)00150-8

Loomis, W. D., and Durst, R. W. (1992). Chemistry and biology of boron. Biofactors 3, 229-239.

Lu, Y. B., Yang, L. T., Li, Y., Xu, J., Liao, T. T., Chen, Y. B., et al. (2014). Effects of boron deficiency on major metabolites, key enzymes and gas exchange in leaves and roots of Citrus sinensis seedlings. Tree Physiol. 34, 608-618. doi: 10.1093/treephys/tpu047

Matoh, T., Kawaguchi, S., and Kobayashi, M. (1996). Ubiquity of a boraterhamnogalacturonan II complex in the cell walls of higher plants. Plant Cell Physiol. 37, 636-640. doi: 10.1093/oxfordjournals.pcp.a028992

Matoh, T., and Kobayashi, M. (1998). Boron and calcium, essential inorganic constituents of pectic polysaccharides in higher plant cell walls. J. Plant Res. 111, 179-190. doi: 10.1007/BF02507164

Mesquita, G. L., Zambrosi, F. C., Tanaka, F. A., Boaretto, R. M., Quaggio, J. A., Ribeiro, R. V., et al. (2016). Anatomical and physiological responses of citrus trees to varying boron availability are dependent on rootstock. Front. Plant Sci. 7:224. doi: 10.3389/fpls.2016.00224

O'Neill, M. A., Eberhard, S., Albersheim, P., and Darvill, A. G. (2001). Requirement of borate cross-linking of cell wall rhamnogalacturonan II for Arabidopsis growth. Science 294, 846-849. doi: 10.1126/science.1062319

O’Neill, M. A., Warrenfeltz, D., Kates, K., Patrice, P., Thierry, D., Alan, G. D., et al. (1996). Rhamnogalacturonan-II, a pectic polysaccharide in the walls of growing plant cell, forms a dimer that is covalently cross-linked by a borate ester. J. Biol. Chem. 271, 22923-22930. doi: 10.1074/jbc.271.37.22923

Pan, Y., Wang, Z., Yang, L., Wang, Z. F., Shi, L., Naran, R., et al. (2012). Differences in cell wall components and allocation of boron to cell walls confer variations in sensitivities of Brassica napus, cultivars to boron deficiency. Plant Soil 354, 383-394. doi: 10.1007/s11104-011-1074-6

Redgwell, R. J., and Selvendran, R. R. (1986). Structural features of cellwall polysaccharides of onion Allium cepa. Carbohydr. Res. 157, 183-199. doi: 10.1016/0008-6215(86)85068-6

Ridley, B. L., O’Neill, M. A., and Mohnen, D. (2001). Pectins: structure, biosynthesis, and oligogalacturonide-related signaling. Phytochemistry 57, 929-967. doi: 10.1016/S0031-9422(01)00113-3

Shen, H., Hou, N. Y., Schlicht, M., Wan, Y. L., Mancuso, S., and Baluška, F. (2008). Aluminium toxicity targets PIN2 in Arabidopsis root apices: effects on PIN2 endocytosis, vesicular recycling, and polar auxin transport. Chin. Sci. Bull. 53, 2480-2487. doi: 10.1007/s11434-008-0332-3

Shkol'Nik, M. Y., Krupnikova, T. A., Timofeeva, S. S., and Stom, D. I. (1981). Intensification of quinone formation from exogenous polyphenols by homogenates of the leaves of sunflower plants reared under conditions of boron deficiency. Fiziol. Rast. 28, 541-546. 
Shorrocks, V. M. (1997). The occurrence and correction of boron deficiency. Plant Soil 193, 121-148. doi: 10.1023/A:1004216126069

Stass, A., Kotur, Z., and Horst, W. J. (2007). Effect of boron on the expression of aluminium toxicity in Phaseolus vulgaris. Physiol. Plant. 131, 283-290. doi: 10.1111/j.1399-3054.2007.00957.x

Tzin, V., and Galili, G. (2010). New insights into the shikimate and aromatic amino acids biosynthesis pathways in plants. Mol. Plant 3, 956-972. doi: 10.1093/mp/ ssq048

Wang, Q. J., Zhang, L., Zhang, J. C., Shen, Q. R., Ran, W., and Huang, Q. W. (2013). Effects of compost on the chemical composition of SOM in density and aggregate fractions from rice-wheat cropping systems as shown by solid-state 13C-NMR spectroscopy. J. Plant Nutr. Soil Sci. 175, 920-930. doi: 10.1002/jpln. 201100350

Wang, R. D., Liu, G. D., Liu, L. C., and Jiang, C. C. (2013). Effects of boron deficiency and excess on rootstock growth and root morphology in trifoliate orange seedlings. J. Food Agric. Environ. 11, 817-823.

Wu, D., Shen, H., Yokawa, K., and Baluška, F. (2015). Overexpressing OsPIN2 enhances aluminium internalization by elevating vesicular trafficking in rice root apex. J. Exp. Bot. 66, 6791-6801. doi: 10.1093/jxb/erv385

Yang, J., and Yen, H. Y. (2002). Early salt stress effects on the changes in chemical composition in leaves of ice plant and Arabidopsis. A Fourier Transform infrared spectroscopy study. Plant Physiol. 130, 1032-1042. doi: 10.1104/pp. 004325

York, W. S., Darvill, A. G., Mcneil, M., and Albersheim, P. (1985). 3-Deoxy-Dmanno-2-octulosonic acid (KDO) is a component of rhamnogalacturonan II, a pectic polysaccharide in the primary cell walls of plants. Carbohydr. Res. 138 109-126. doi: 10.1016/0008-6215(85)85228-9

Yu, Q., Hlavacka, A., Matoh, T., Volkmann, D., Menzel, D., Goldbach, H. E., et al. (2002). Short-term boron deprivation inhibits endocytosis of cell wall pectins in meristematic cells of maize and wheat root apices. Plant Physiol. 130, 415-421. doi: 10.1104/pp.006163

Zhou, G. F., Peng, S. A., Liu, Y. Z., Wei, Q. J., Han, J., and Islam, M. Z. (2014). The physiological and nutritional responses of seven different citrus rootstock seedlings to boron deficiency. Trees 28, 295-307. doi: 10.1007/s00468-0130949-y

Zhou, X. X., Yang, L. T., Qi, Y. P., Guo, P., and Chen, L. S. (2015). Mechanisms on boron-induced alleviation of aluminum-toxicity in Citrus grandis seedlings at a transcriptional level revealed by cDNA-AFLP analysis. PLOS ONE 10:e0115485. doi: 10.1371/journal.pone.0115485

Conflict of Interest Statement: The authors declare that the research was conducted in the absence of any commercial or financial relationships that could be construed as a potential conflict of interest.

Copyright (C) 2017 Wu, Riaz, Yan, Du, Liu and Jiang. This is an open-access article distributed under the terms of the Creative Commons Attribution License (CC BY). The use, distribution or reproduction in other forums is permitted, provided the original author(s) or licensor are credited and that the original publication in this journal is cited, in accordance with accepted academic practice. No use, distribution or reproduction is permitted which does not comply with these terms. 